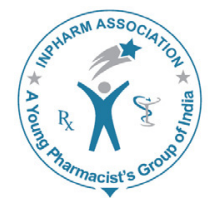

\title{
Effect of Frusemide on Serum and Urinary Zinc levels in Rabbits
}

\author{
Sangeeta P Bhat* and Rahat Ali Khan \\ Department of Pharmacology, Jawaharlal Nehru Medical College, Aligarh Muslim University, \\ Aligarh-202002, India.
}

\begin{abstract}
Introduction: Zinc is an essential trace element playing a vital role in the maintenance of health. Frusemide, a loop diuretic, is known to deplete sodium, potassium, magnesium and calcium levels. But, very few reports exist on its effect on Zinc levels. Hence, this study was performed on rabbits to investigate the same in detail. Material \& Methods: Healthy adult New Zealand White rabbits ( $\mathrm{n}=6$ per group) were treated with Normal saline $\left(2 \mathrm{ml} \mathrm{kg}{ }^{-1}\right)$ and Frusemide $(5,10$ or $15 \mathrm{mg}$ $\mathrm{kg}^{-1}$ each) intraperitoneally. Their serum and urinary zinc levels were studied by Atomic Absorption Spectrophotometry. Analysis of serum Zinc levels was also done after dietary Zinc supplementation for 20 days. Results: A dose-dependent decrease in serum Zinc levels owing to increased urinary Zinc excretion was observed. Both the urinary volume and urinary Zinc concentration increased dose-dependently. The percent fall in serum Zinc occurred in proportion to the pre-treatment serum values. Administration of Zinc in the diet restored the serum Zinc levels to normal. Conclusion: Frusemide may be responsible for Zinc depletion. Supplementation of Zinc may help to prevent the same in patients on prolonged Frusemide therapy.
\end{abstract}

Key words: Dose-dependent, Frusemide, Frusemide-induced complications, Hypozincaemia, Hyperzincuria, Rabbits.

\section{INTRODUCTION}

Zinc, atomic number 30, is a metallic transition element is an important trace element in the body. Nearly $10 \%$ of the proteins encoded in the mammalian genome require zinc for their proper structure and function. ${ }^{1,2}$ Over 70 zinc metalloenzymes are required for carbohydrate, protein, lipid and nucleic acid metabolism. ${ }^{3}$ Other zinc metalloproteins are involved in diverse processes such

\begin{tabular}{|c|l|}
\hline \multicolumn{2}{|c|}{ Access this article online } \\
\hline \multirow{2}{*}{ Journal Sponsor } & \\
\hline \multirow{2}{*}{ www.phcognet } & $\begin{array}{l}\text { Website: } \\
\text { www.jyoungpharm.org }\end{array}$ \\
\cline { 2 - 3 } & DOI: \\
& $10.5530 /$ jyp.2015.3.17 \\
& \\
\hline
\end{tabular}

as cell signalling, gene expression, membrane structure and function, modulation of the redox state of the cell and cellular respiration. ${ }^{4,5}$ Mild zinc deficiencies can cause chronic metabolic derangement leading to or exacerbating immune deficiency, gastrointestinal problems, endocrine disorders, neurologic dysfunction, cancer, accelerated aging and degenerative disease. ${ }^{6}$

Loop diuretics are used in numerous conditions such as CHF, HTN, renal diseases and other oedematous conditions. Frusemide causes a decrease in the serum sodium, potassium, calcium and magnesium levels and an increase in serum uric acid and glucose levels. ${ }^{7}$ But, there are sparse and inconclusive reports on its effect on serum Zinc levels. ${ }^{8,9}$ Thus, we have investigated the effect of Frusemide on serum and urine Zinc levels in rabbits.

*Address for correspondence:

Dr. Sangeeta P Bhat, Resident, Department of Pharmacology, Jawaharlal Nehru Medical College, Aligarh Muslim University Aligarh-202002, India.E-mail : sweetsan18@yahoo.com 


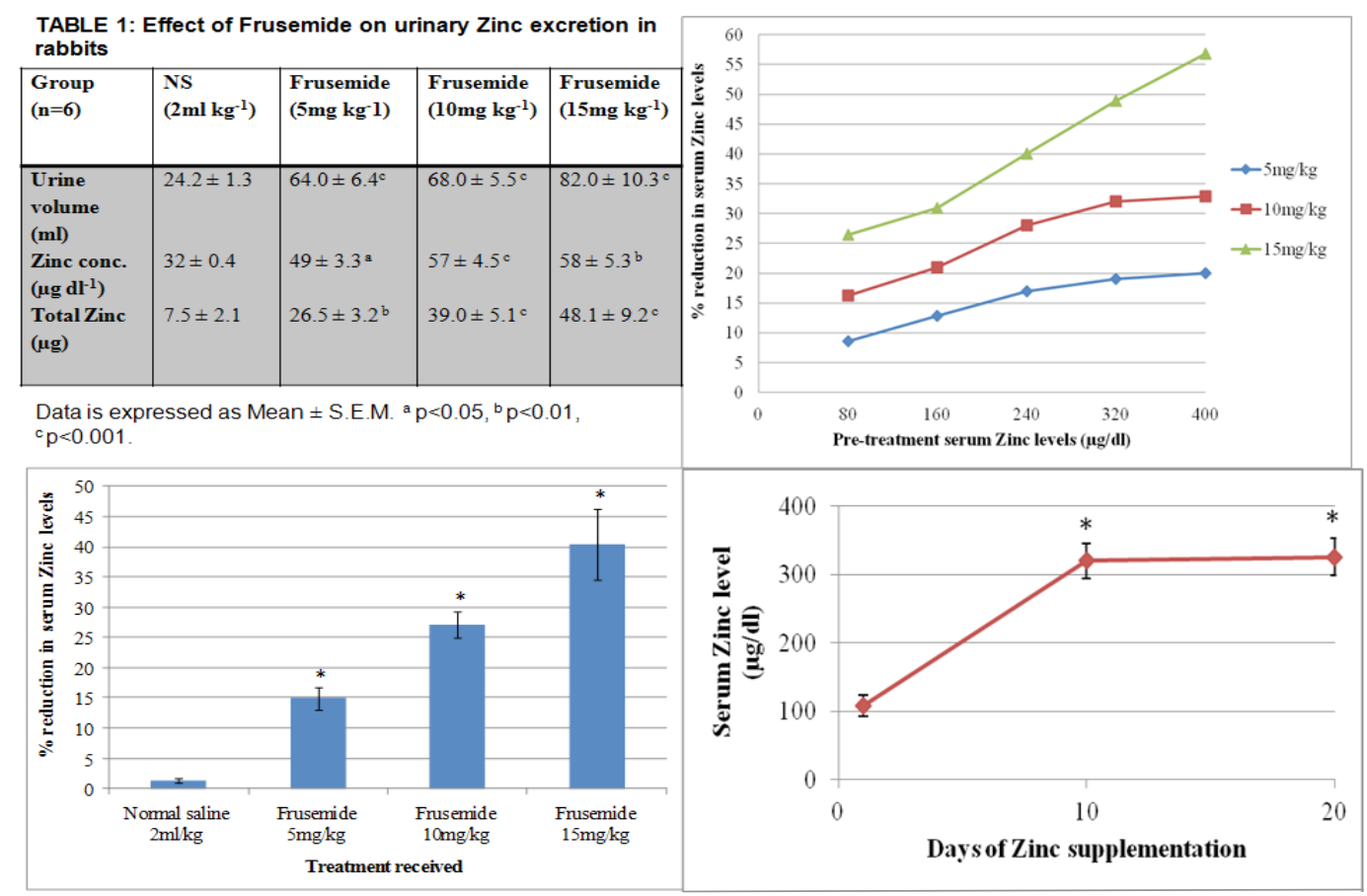

Graphical Abstract

\section{MATERIALS AND METHODS}

\section{Experimental animals}

The study was approved by the Institutional Animal Ethics Committee. Healthy, adult, male New Zealand White rabbits $(1.5-2 \mathrm{~kg})$ were obtained from the Institutional Central Animal House and housed individually in wire bottomed cages, maintained under standard conditions (Temperature $=27 \pm 2{ }^{0} \mathrm{C}$, Humidity $=30-70 \%, 12 \mathrm{hr}$ lightdark cycle). Standard laboratory pellet diet \& water ad libitum was provided and were acclimatized to laboratory conditions for 7 days prior to experimentation. All animal experiments were conducted in accordance with the CPCSEA Guidelines, 2003. ${ }^{10}$

\section{Experimental design}

The animals were randomly divided into 4 groups of 6 animals each. They were administered single intraperitoneal injection of N. saline (control) and Frusemide (5, 10 \& 15 $\mathrm{mg} / \mathrm{kg}$ ) in groups 2,3 and 4 respectively on $1^{\text {st }}, 10^{\text {th }}$ and $20^{\text {th }}$ day. Diet was supplemented with Zinc sulphate (Elemental Zinc $=6 \mathrm{mg} / \mathrm{rabbit}$ ) for 20 days.

\section{SAMPLES}

Blood samples from marginal ear vein of each rabbit before and 4 hours after drug administration on $1^{\text {st }}, 10^{\text {th }}$ and $20^{\text {th }}$ day were obtained and centrifuged (4000 rpm for $15 \mathrm{~min}$ ).
The serum obtained was stored in vials at $-4^{0} \mathrm{C}$ till further usage. The urine was also collected from rabbits placed in metabolic cages till 4 hours after drug administration on the same days, filtered and stored at $-4^{0} \mathrm{C}$ till further usage.

\section{ATOMIC ABSORPTION SPECTROPHOTOMETRY}

Serum and urine samples were analysed for Zinc levels on an Atomic Absorption Spectrophotometer (4139-ECIL) and values were obtained in triplicate.

\section{STATISTICAL ANALYSIS}

Data is expressed as Mean \pm S.E.M. and analyzed using Paired Sample t-test and one-way ANOVA with post hoc Dunnett's test where required. P values $<0.05$ were considered significant.

\section{RESULTS}

\section{EFFECT OF FRUSEMIDE ON SERUM ZINC LEVELS}

As shown in Figure 1, the control group showed insignificant change in serum Zinc levels with a minute reduction by $1.25 \%$, whereas, the test groups $(2,3$ and 4) showed significant $(\mathrm{p}<0.001)$ and dose-dependent reduction in serum Zinc levels by $14.9 \%, 27.1 \%$ and $40.4 \%$ after 5, 10 and $15 \mathrm{mg} / \mathrm{kg}$ Frusemide injection respectively when compared to their pre-test values.

Journal of Young Pharmacists Vol $7 \bullet$ Issue $3 \bullet$ Jul-Sep 2015 


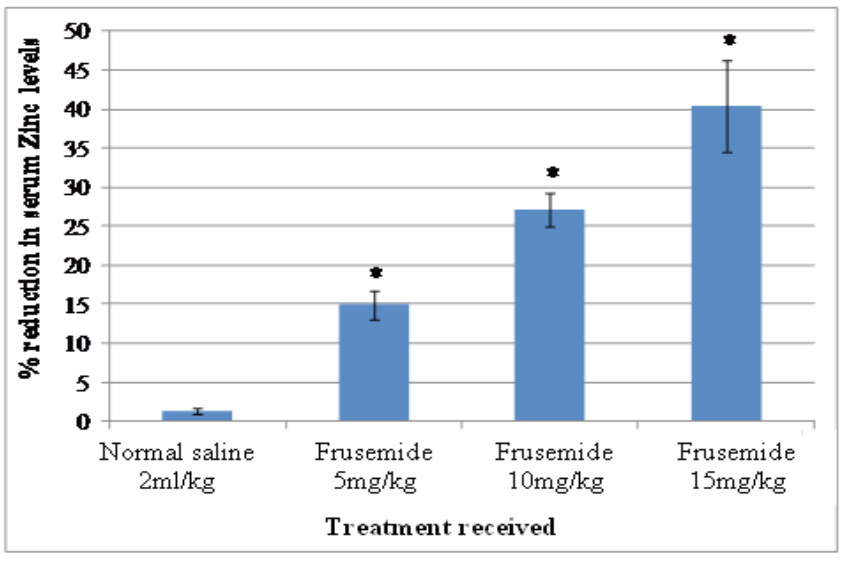

Figure 1:\% reduction in Serum Zinc levels following frusemide injection (i.p.)

The figure represents \% reduction in serum Zinc levels following Frusemide injection (5, 10 and $15 \mathrm{mg} \mathrm{kg}^{-1}$ i.p.). Data presented: Mean \pm S.E.M. ${ }^{*} \mathrm{p}<0.001$. Normal saline $=1.25 \pm 0.4 \%$, Frusemide $5 \mathrm{mg} \mathrm{kg}^{-1}=14.9 \pm 1.8 \%$, Frusemide 10 $\mathrm{mg} \mathrm{kg}^{-1}=27.1 \pm 2.1 \%$, Frusemide $15 \mathrm{mg} \mathrm{kg}^{-1}=40.4 \pm 5.9 \%$.

\begin{tabular}{|c|c|c|c|c|}
\hline $\begin{array}{l}\text { Group } \\
(n=6)\end{array}$ & $\begin{array}{c}\text { NS } \\
2 \mathrm{mlkg}^{-1}\end{array}$ & $\begin{array}{l}\text { Frusemide } \\
5 \mathrm{mg} \mathrm{kg}^{-1}\end{array}$ & $\begin{array}{l}\text { Frusemide } \\
10 \mathrm{mg} \mathrm{kg}^{-1}\end{array}$ & $\begin{array}{c}\text { Frusemide } \\
15 \mathrm{mg} \mathrm{kg}^{-1}\end{array}$ \\
\hline $\begin{array}{l}\text { Urine volume } \\
\qquad(\mathrm{ml})\end{array}$ & $24.2 \pm 1.3$ & $64.0 \pm 6.4^{c}$ & $68.0 \pm 5.5^{c}$ & $82.0 \pm 10.3^{c}$ \\
\hline $\begin{array}{l}\text { Zinc conc } \\
\qquad\left(\mu \mathrm{g} \mathrm{dl}^{-1}\right)\end{array}$ & $32 \pm 0.4$ & $49 \pm 3.3^{a}$ & $57 \pm 4.5^{c}$ & $58 \pm 5.3^{b}$ \\
\hline $\begin{array}{c}\text { Total Zinc } \\
(\mu \mathrm{g})\end{array}$ & $7.5 \pm 2.1$ & $26.5 \pm 3.2^{b}$ & $39.0 \pm 5.1^{c}$ & $48.1 \pm 9.2^{c}$ \\
\hline
\end{tabular}

Data is expressed as Mean \pm S.E.M. ${ }^{a} p<0.05,{ }^{b} p<0.01,{ }^{c} p<0.001$

It was also observed that the reduction by Frusemide injection in serum Zinc levels was dependent on the pretreatment values. With lower serum Zinc values on Day 1 , the reduction was less which increased on $10^{\text {th }}$ and $20^{\text {th }}$ day following Zinc supplementation with higher initial Zinc levels. The change had a direct proportion as shown in Figure 2.

\section{EFFECT OF FRUSEMIDE ON URINARY ZINC EXCRETION}

As shown in Table 1, the mean urine volume in control group was $24.2 \pm 1.3 \mathrm{ml}$. Frusemide injection caused a significant $(\mathrm{p}<0.001)$ and dose-dependent increase in urine volume $(64.0 \pm 6.4,68.0 \pm 5.5,82.0 \pm 10.3 \mathrm{ml})$ with 5,10 and $15 \mathrm{mg} / \mathrm{kg}$ doses respectively when compared to the control groups. Urinary Zinc concentration in control was $32 \pm 0.4 \mu \mathrm{g} / \mathrm{dl}$ which increased to $49 \pm 3.3(\mathrm{p}<0.05), 57 \pm$ $4.5(\mathrm{p}<0.001)$ and $58 \pm 5.3(\mathrm{p}<0.001) \mu \mathrm{g} / \mathrm{dl}$ in 5,10 and 15 $\mathrm{mg} / \mathrm{kg}$ Frusemide treated rabbits respectively. The changes were statistically significant. Total amount of urinary Zinc was also increased significantly following Frusemide injection; $26.5 \pm 3.2(\mathrm{p}<0.01), 39.0 \pm 5.1(\mathrm{p}<0.001)$ and

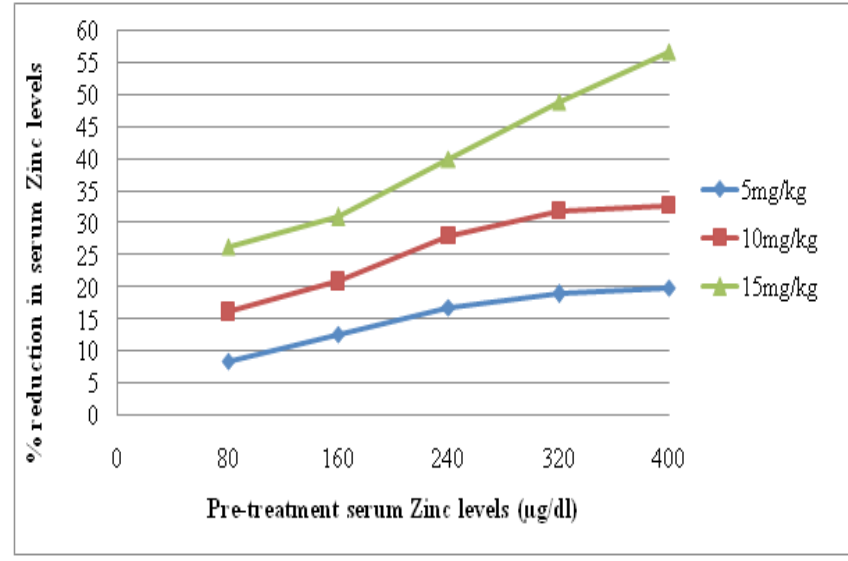

Figure 2: Effect of 5, 10 and $15 \mathrm{mg} \mathrm{kg}^{-1}$ Frusemide on Serum Zinc levels following Zinc supplementation in diet

Each curve represents the distribution of $\%$ reduction in 18 pre-treatment Serum Zinc levels of 6 rabbits obtained on $1^{\text {st }}, 10^{\text {th }}$ and $20^{\text {th }}$ day of Zinc supplementation.

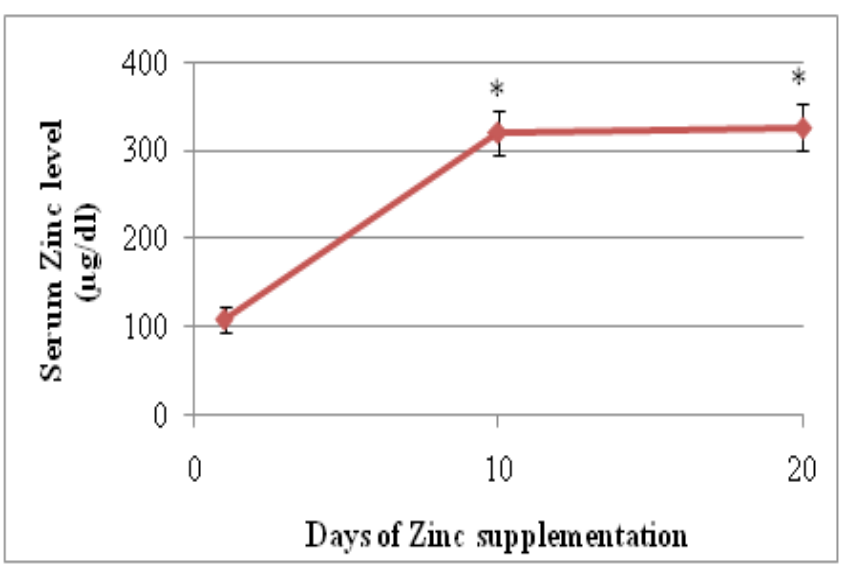

Figure 3: Change in serum zinc levels $\left(\mu \mathrm{g} \mathrm{dl}^{-1}\right)$ following zinc supplementation in diet

The curve represents rise in Serum Zinc levels $\left(\mu \mathrm{g} \mathrm{dl}^{-1}\right)$ following zinc supplementation in diet as measured on days 1,10 and 20 in 24 rabbits. ${ }^{*} p<0.01$. Day $0=108.2 \pm 15.7 \mu \mathrm{g} \mathrm{dl}^{-1}$, Day $10=320.2 \pm 25.4 \mu \mathrm{g} \mathrm{dl}^{-1}$, Day $20=326.0 \pm 26.7$ $\mu \mathrm{g} \mathrm{dl}^{-1}$.

$48.1 \pm 9.2(\mathrm{p}<0.001) \mu \mathrm{g}$ with 5,10 and $15 \mathrm{mg} / \mathrm{kg}$ doses respectively when compared to control $(7.5 \pm 2.1 \mu \mathrm{g})$.

\section{CHANGE IN SERUM ZINC LEVELS ( $\mu \mathrm{g} / \mathrm{dl})$ FOLLOWING ZINC SUPPLEMENTATION IN DIET}

As shown in Figure 3, the normal mean serum Zinc levels in pre-treated rabbits $(\mathrm{n}=24)$ ranged from 89 to $159 \mu \mathrm{g} / \mathrm{dl}$ (Mean \pm S.E.M., $108.2 \pm 65.7 \mu \mathrm{g} / \mathrm{dl}$ ) on the $1^{\text {st }}$ day of study. Zinc supplementation in diet caused a gradual rise in serum Zinc levels which reached 268-396 (Mean \pm S.E.M., 320.2 $\pm 25.4) \mu \mathrm{g} / \mathrm{dl}$ on $10^{\text {th }}$ day; the increase $196 \%(\mathrm{p}<0.01)$ was significant as compared to $1^{\text {st }}$ day values. Supplementation for next 10 days further increased the Zinc levels slightly in all the rabbits on $20^{\text {th }}$ day, ranging from 271 to $420 \mu \mathrm{g} / \mathrm{dl}$ $(326.0 \pm 26.7 \mu \mathrm{g} / \mathrm{dl}$, Mean \pm S.E.M.). the increase $(202 \%$, $\mathrm{p}<0.01$ ) was statistically similar to the $10^{\text {th }}$ day. 


\section{DISCUSSION}

This is the first study to be dealing with the relationship between Frusemide and Zinc in such detail. Although Zinc is excreted mainly by the gastrointestinal route, ${ }^{11}$ it is obvious from the study that Frusemide leads to a highly significant and dose-dependent fall in serum Zinc levels through urinary excretion. The significant rise in urinary excretion of Zinc is inclusive of both the total Zinc content and the urinary Zinc concentration. The regulation of urinary zinc losses is not well understood. Possibly, the shifts in urinary zinc excretion are mediated by adjustments in renal tubular zinc transport. ${ }^{12}$ Experiments with cysteine infusion in anesthetized dogs have demonstrated that the nephron is capable of both proximal secretion and distal reabsorption of $\mathrm{Zn} .{ }^{13}$ Thus, Frusemide might be causing an increase in the proximal tubular secretion of Zinc. The fall in serum Zinc levels is more with initially high serum Zinc levels as compared to initially low serum Zinc levels. Hence, the body tries its best to maintain a constant level of serum Zinc by adjusting the percentage of urinary excretion according to the pre-treatment values.

There are some reports of Zinc toxicity due to chronic exposure in metal industries, ${ }^{14}$ excessive supplementation and food poisoning due to storage of food items in galvanised containers. ${ }^{15-17}$ Hence, Frusemide may be used as a therapeutic agent in hyperzincaemia \& zinc poisoning.

It is an established fact that loop diuretics can cause hyperglycemia and hyperuricemia. ${ }^{7}$ Since, the role of Zinc in insulin synthesis and secretion has been established over the years, ${ }^{18-21}$ it is possible that hypozincaemia caused by chronic Frusemide administration may lead to hyperglycemia in normal individuals and deteriorate the condition further in diabetics.
Both Zinc and Copper must be present in order to minimize oxidative damage in arthritis and in proper functioning of enzymes like Xanthine oxidase and Superoxide dismutase. ${ }^{22}$ These enzymes play the prime role in gout. Thus, zinc deficiency might lead to precipitation of an attack of gout and might possibly be one of the mechanisms behind frusemide-induced hyperuricemia. Apart from this, Zinc depletion causing decreased testosterone production may lead to infertility ${ }^{23,24}$ and increased inflammatory response. ${ }^{25}$ And, as shown here, administration of Zinc in diet restored the normal serum Zinc levels indicating that supplementation of Zinc with Frusemide might help to prevent these complications.

With respect to the importance of zinc as an essential element and frequency of diuretic treatment, the observed increased urinary losses of zinc deserve further attention. Moreover, it would be advisable to supplement Zinc along with Frusemide therapy to prevent/reduce the latter's adverse effects.

\section{CONCLUSION}

Frusemide may be responsible for Zinc depletion. Supplementation of Zinc may help to prevent the same in patients on prolonged Frusemide therapy.

\section{CONFLICT OF INTEREST}

We declare that we have no conflict of interest.

\section{SOURCE OF SUPPORTS}

R.A.K. designed the study, analyzed the data and supervised the study. S.P.B. administered the experiment, collected output data and wrote the manuscript.

\section{Author Profile}

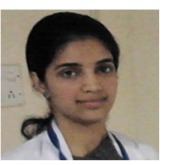

- Dr. Sangeeta P. Bhat is a final year MD Pharmacology resident at Jawaharlal Nehru Medical College, Aligarh whose main objectives are to cultivate good research skills and gain sound knowledge in the field of drug development and to pursue a career/PhD in the development of targeted drugs from medicinal plants.

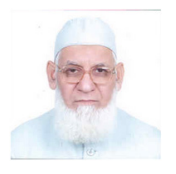

- Dr. Rahat Ali Khan is presently serving as Professor Department of Pharmacology J. N. Medical College Aligarh Muslim University Aligarh India. he is involved in teaching and research for more than 3 decades. Thrust areas of his research are Neuropharmacology, Clinical Pharmacology, Immunopharmacology, Trace element studies, Autacoids-Histamine and Indigenous drugs. 


\section{Highlights of Paper}

- Zinc is an essential trace element playing a vital role in the maintenance of health.

- Frusemide administration causes a dose-dependent decrease in serum Zinc levels.

- The decrease in serum Zinc is due to the increased urinary volume and urinary Zinc concentration dose-dependently.

- The percent fall in serum Zinc occurred in proportion to the pre-treatment serum values.

- Administration of Zinc in the diet restored the serum Zinc levels to normal.

\section{REFERENCES}

1. Vallee $\mathrm{BL}$, Falchuk KH. The biochemical basis of zinc physiology. Physiol Rev. 1993; 73(1): 79-118.

2. Andreini C, Banci L, Bertini I, Rosato A. Counting the zinc-proteins encoded in the human genome. J Proteome Res. 2006; 5(1): 196-201.

3. Colombini S. Canine zinc-responsive dermatosis. Vet Clin North Am Small Anim Pract. 1999; 29(6): 1373-1383.

4. Frassinetti S, Bronzetti G, Caltavuturo L, Cini M, Croce CD. The role of zinc in life: a review. J Environ Pathol Toxicol Oncol. 2006; 25(3): 597-610.

5. Hambidge M. Human zinc deficiency. J Nutr. 2000; 130(5): 1344S-9S.

6. Cummings JE, Kovacic JP. The ubiquitous role of zinc in health and disease. J of Vet Emer and Crit Care. 2009; 19(3): 215-40.

7. Reilly RF, Jackson EK. Regulation of Renal Function and Vascular Volume. In: Brunton L, Chabner B, Knollman B, editors. Goodman \& Gilman's The Pharmacological Basis of Therapeutics, $12^{\text {th }}$ edn. China: The McGraw-Hill Companies Inc; 2011. p. 685-6.

8. Wester PO. Urinary zinc excretion during treatment with different diuretics. Acta Med Scand. 1980; 208(3): 209-12.

9. Cohen N, Goik A. Zinc balance and medications commonly used in the management of heart failure. Heart Fail Rev. 2006; 11(1): 19-24.

10. CPCSEA guidelines for laboratory animal facility. Indian J Pharm. 2003; 35(4): 257-74.

11. Krebs N. Overview of Zinc Absorption and Excretion in the Human Gastrointestinal Tract. J Nutr. 2000; 130(5): 1374S—7S.

12. King JC, Shames DM, Woodhouse LR. Zinc Homeostasis in Humans. J Nutr. 2000; 130(5): 1360S—6S.

13. Abu-Hamdan DK, Migdal SD, Whitehouse R, Rabbani P, Prasad AS, McDonald FD. Renal handling of zinc: effect of cysteine infusion. Am J Physiol. 1981; 24(15): F487-94.

14. Plum LM, Rink L, Haase $H$. The Essential Toxin: Impact of Zinc on Human Health. Int. J Environ Res Public Health. 2010; 7(4): 1342-65.

15. Brown MA, Thom JV, Orth GL, Cova P, Juarez J. Food poisoning involving zinc contamination. Arch Environ Health. 1964; 8(5): 657-60.

16. Fox MRS. Zinc excess. In: Mills CF (ed). Zinc in Human Biology. Springer Verlag: New York, 1989. p. 366-8.

17. Fosmire GJ. Zinc toxicity. Am J Clin Nutr. 1990; 51(2): 225-7.

18. Zhou H, Zhang T, Harmon JS, Bryan J, Robertson RP. Zinc, Not Insulin, Regulates the Rat Alpha Cell Response to Hypoglycaemia in vivo. Diabetes 2007; 56(4): 1107-12.

19. Haase $H$, Overbeck $S$, Rink L. Zinc supplementation for the treatment or prevention of disease: Current status and future perspectives. Exptl Gerontology. 2008; 43(5): 394-408.

20. Jansen J, Karges W, Rink L. Zinc and diabetes - clinical links and molecular mechanisms. J Nutrl Biochem. 2009; 20(6): 399-417.

21. Rungby J. Zinc, zinc transporters and diabetes. Diabetologia 2010; 53(8): 1549-51.

22. Johnson S. Effect of gradual accumulation of iron, molybdenum and sulfur, slow depletion of zinc and copper, ethanol or fructose ingestion and phlebotomy in gout. Med Hypotheses. 1999; 53(5): 407-12.

23. Huen SC, Goldfarb DS. Adverse Metabolic Side Effects of Thiazides: Implications for Patients With Calcium Nephrolithiasis. J Urology. 2007; 177(4): 1238-43.

24. Shaw NA, Dickey HC, Brugman HH, Blamberg DL, Witter JF. Zinc deficiency in female rabbits. Lab Animals 1974; 8(1): 1-7.

25. Denko CW. Copper and zinc in inflammation. Inflammation and Drug Therapy Series. 1989; 4: 1-5. 